\title{
Kernos
}

Revue internationale et pluridisciplinaire de religion grecque antique

8| 1995

Varia

\section{Zeus' tomb. An object of pride and reproach}

\section{Minos Kokolakis}

URL: http://journals.openedition.org/kernos/596

DOI: 10.4000/kernos.596

ISSN: 2034-7871

\section{Publisher}

Centre international d'étude de la religion grecque antique

\section{Printed version}

Date of publication: 1 January 1995

Number of pages: 123-138

ISSN: 0776-3824

\section{Electronic reference}

Minos Kokolakis, «Zeus' tomb. An object of pride and reproach », Kernos [Online], 8| 1995, Online since 11 April 2011, connection on 02 May 2019. URL : http://journals.openedition.org/kernos/596 ; DOI :

10.4000/kernos.596 


\section{Zeus' tomb. An object of pride and reproach}

I. In his account of Antiochus from Aegae ${ }^{1}$, Flav. Philostratus praises the sophist's efficiency in declamation based "on a sure grasp of arguments, intensity in accusation and invective as well as on brilliance in the genre of 'apologies'". Amongst the latter the biographer of the 2nd Sophistic singles out Antiochus' melete in defence of "the Cretans standing trial for the grave of Zeus ${ }^{2 \prime}$. Incidentally, it is surprising that this testimonium is not entered in R.Kohl's copious catalogue of declamatory topics ${ }^{3}$. Concerning the contents of the above "melete", besides vague and rhetorical statements to the effect that Antiochus gave a splendid performance by drawing material from $\varphi v \sigma i o \lambda o \gamma i \alpha \tau \varepsilon$

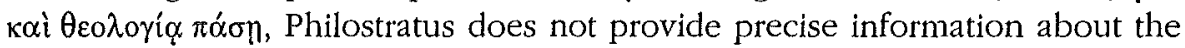
arguments adduced by the defendants or by the hypothetical counsel for their defence.

As Philostratus' text is the unique evidence available so far of Zeus' grave being handled as a subject of declamation, one has to presume at least a great deal of personal resourcefulness on the part of Antiochus to vindicate the awkward paradox of Zeus' burial, so strikingly contrary to the familiar Greek concept of the supreme god. A particular approach that the sophist may have given to his argumentation will be proposed later.

It is acknowledged that references ${ }^{4}$ to graves of other divinities as well (Dionysus, Apollo, Asklepius, Cronus, Poseidon, Aphrodite, Ares, Helios, Hermes, Selene, Isis and Osiris) occur indeed in literary sources. This phenomenon in particular recently led $\mathrm{H}$. Verbruggen ${ }^{5}$ to grant a genuinely Greek identity to Kretagenes Zeus. His thesis, however, refuting a firmly

1 P. Anteios Antiochus (c. 160 - 230 A.D.), contemporary of Philostratus: F. BUECHELER, Miscellen, in RbM, 61 (1906), p. 626; cf. A. STEIN, in PIR ${ }^{2}$ I (1933), p. 135-136, $\mathrm{n}^{\circ} 730 ; \mathrm{J}$. \& L. RoBErT, La Carie, II, Paris, 1954, p. 318-319; G.W. BOWERSOCK, Approaches to the Second Sophistic, Harvard Univ., 1974, p. 36.

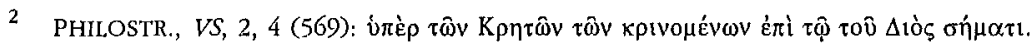

3 De scholast. declamationum argumentis ex bistoria petitis (Rbetorische Studien IV), Paderbonae, 1915.

4 Fr. PFISTER, Der Reliquienkult im Altertum, Giessen, 1909, p. 385-391; A. St. PEASE, M.T. Cicero, De natura deorum II-III, Cambridge Mass., 1958, p. 1097.

5 H. VERBRUGGEN, Le Zeus crétois, Paris, 1981. 
established conviction in a prehellenic stratum ${ }^{6}$ underlying the cult of the Cretan Zeus, has met with scepticism or blunt rebuttals ${ }^{7}$.

To begin with, references and allusions to Zeus' burial place are more numerous ${ }^{8}$ and, significantly, all confined to Crete. Moreover, in the light of a persistent Minoan theology of a youthful vegetation god who dies and is reborn every year, certain festivals and rites performed there through the Christian era can make sense. The most notable of these are: a) The invocation of the Kouretes of Palaikastro to the "Kroneian greatest Kouros" of Dicte to reappear

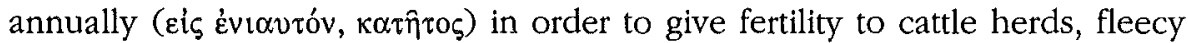
flocks and the fields as well as good fortune and bliss to the cities of eastern Crete; b) The yearly celebrations in honour of (Zeus) Velchanos - depicted on coins as a beardless, i.e. young, figure, or in bird form- associated with a goddess and "hieros gamos"; c) The evidence of continuity of worship from LM period to the 4 th cent. A.D. deduced from finds of recent excavations at the Idaean cave ${ }^{9}$; d) The story told in the Metamorpboses ${ }^{10}$ of Antoninus Liberalis, who quotes from the hellenistic poem Ornitbolog $y^{11}$, to the effect that a miraculous fire flashes annually from the Idaean (?) cave "when the blood from Zeus' bitth streams forth"12; and finally, e) Porphyry's account of the ceremony of the god's throne "being strewn with carpets every year"13 - though the contextual information concerning Pythagoras' descent and the funeral sacrifice within the cave including his own inscribing of the epitaph on Zeus' tomb may be discarded as fanciful ${ }^{14}$ or anachronistic. Accordingly, the persisting worship of a Zeus presumably conflated at an early stage with an indigenous fertility divinity accounts for the various sites on the island which were venerated as the burial (and rebirth) places of the Cretan god: (i) Quoting from Ennius' (239-169

6 A.B. COOK, Zetus, II, Cambridge, $1925^{2}$, p. 940; J.E. HARrISON, Themis, Cambridge, 1927, passim; M.P. NILSSON, The Minoan-Mycenaean Religion, I, Lund, 19502, p. 555-556; ID., Gescbichte der grlech. Religion, I, München, $1967^{3}$, p. 321-322; R.F. WILLETTS, Cretan Cults and Festivals, London, 1962, p. 80, 91-92, 199 sq; M.L. WEST, The Dictaean Hymn to the Kouros, in JHS, 85 (1965), p. 154-155; ID., Hesiod, Theogony, Oxford, 1978 [1966], p. 291; B.C. DIETRICH, The Orlgins of Greek Religion, Berlin-New York, 1974, p. 13-17; Y. DUHOUX, in RBPh, 61 (1983), p. 236-237, etc.

$7 \quad E . g$, in WS, 17 (1983), p; 254; CR, 33 (1983), p. 144-145; REG, 96 (1983), p. 295; RBPb, 61 (1983), p. 236-237. Favourable comments in $G E R, 30$ (1983), p. 109 and $R H R, 200$ (1983), p. 432-433; a

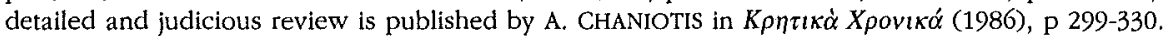

8 Amounting to 43: P. FAURE, Le mont Jouktas, tombeau de Zeus, in Minotca, Festschrift Iob. Sundwall, Berlin, 1958, p. 134; cf. A.B. COOK, op. cit. (n. 6), p. 940-943 and ID., I, p. 157, n. 4.

9 J.A. SAKELLARAKIS, The Idaean Cave. Minoan and Greek Worship, in Kernos, 1 (1988), p. 207-214.

10 Ch. 19, 1-2. Antoninus Liberalis is dated c. 200 A.D. (M. PAPATHOMOPOULOS, Ant. Liberalls, Les Métamorphoses, Paris, 1968, p. IX).

11 By a certain poet Boios (assuming the name of an ancient Delphic priestess Botó).

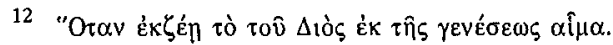

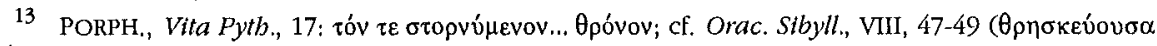
Apóvariv).

14 Cf. E. ROHDE, Psycbe, I, Tübingen, $1925^{9 / 10}$, p. 129 , n. 3. 
B.C.) work Eubemerus or Sacra Scriptio (or Sacra Historia) Lactantius (c. 250325 A.D.) names Cnossus ${ }^{15}$ as the locality of the grave, adding that in it est inscriptum antiquis litteris Graecis ZAN KPONOY id est Latine Juppiter Saturni ${ }^{16}$. (ii) It is in the Idaean cave, where Varro ${ }^{17}$ sets Zeus' tomb affirming that it is a spot of pilgrimage in his own days. The same location is taken up later by Porphyry (3rd cent. A.D.) in his tale of Pythagoras' cult practice there. (iii) According to Nonnus' (5th cent. A.D.) Dionysiaka $(8,117)$ Apate used to stay on mount Dikte "by the false tomb of Zeus" ( $\Delta$ iò $\zeta \psi \varepsilon v \delta \dot{n} \mu$ ovı $\tau \dot{v} \mu \beta \omega$ ). (iv) Finally, though ancient sources never mention mount Juktas as Zeus' burial ground $^{18}$ local hearsay brought (Sept. 1415) the clergyman Cristoforo Buondelmonti to recognize within a cave to the north of the mountain sepulcrum Iovis Maximi and an epitaph "with letters totally effaced"19. He was to acquiesce, he says, in what local people told him because he realized per totam insulam ita esse provulgatum. However, later travellers echoing ancient sources aired different views, either conveying the alleged monument to the mountain peak or near Cnossus or on mount Ida or relating it to the legendary cave and burial place of Minos.

Apparently the literary allusions or references to the display of Zeus' tomb are not traceable ${ }^{20}$ earlier than the 4 th cent. B.C.; yet the story becomes increasingly talked of in the following centuries ${ }^{21}$ as a salient feature of Cretan mythomania ${ }^{22}$. Nevertheless, judging from the traces of prehellenic religious ideas identified in later periods one is reluctant to agree that the 4 th cent. B.C. marks the creation of the tale of Zeus' grave or blame the whole story on certain writers, notably Euhemerus and Callimachus.

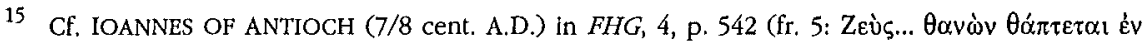

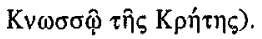

16 LACTANT, Divinae Institutiones, 1, 11, 46 ( = T 69 A in M. WINIARCZYK, Evbemeni Messenit Reliquiae, Stuttgart-Leipzig, Teubner, 1991). The alleged epitaph with slight variations is recorded in numerous Hellenistic and Byzantine texts including the epigram Anthol. Palat, VII, 746 ascribed to Pythagoras (see supra, n. 13).

17 According to SOLIN. (soon after 200 A.D.), Collectanea, 11, 6-7; Varro probably visited the cave himself (C. ClCHORIUS, Römiscbe Studien, Leipzig-Berlin, 1961² [1922], p. 212).

18 Pace A. KARETSOU, The Peak Sanctuary of Mt. Juktas, in Proceedings of the 1st Intern. Symposium of the Suedish Institute at Atbens 1980, Stockholm, 1981, p. 153, and E.F. BLOEDOW, Evidence for an early Date for the Cult of Cretan Zeus, in Kernos, 4 (1991), p. 162; P. FAURE, Minoica, art. cit. (n. 8), p. 135, rightly stated: "de toutes façons, le mont Iouktas semble exclu de la tradition antique".

19 Cr. BUONDELMONTI, Descriptio insule Crete et Liber insularum, cap. XI: Creta, 154 (685-690), ed. by M.-A. VAN SPITAEL, Herakleion, 1981.

20 Cf. VERBRUGGEN, op. cit. (n. 5), p. 82-83.

21 The topic is exploited by LuCIAN no less than five times: De sacr., 10; Tim., 6; Zeus Trag, 45; Pbilops., 3; Deor. Concil., 6; cf. [Pbilop.] 10.

22 POMP. MELA, De Chorographia, 2, 112: Crete multis famigerata fabulis... maxime tamen eo quod tbi sepulti Iovis paene clarum vestigium sepulcmim; cf. DIOD. SIC., $3,61$. 
It is for the most part round these two figures that the following discussion will revolve, not as being really the originators of the legend but because subsequent generations quoted them as pivotal authorities in support of diametrically opposed versions of the subject of Zeus' grave: as an object to be proud of or as a cause for condemnation.

II. In the proem to his convivial Hymn to Zeus Callimachus (310-c. 240 B.C.) wavers between two rival claims: the one of the Cretan Dicte, the other of the Arcadian mount Lycaeum as the birthplace of Zeus. The poet elicits a solution from the notorious saying ascribed to Epimenides: "Cretans are always liars"23. Callimachus endorses this verdict with a supplementary proof of its validity: "Indeed, the Cretans even contrived a tomb for you, O Lord; but you did not die, for you live for ever" ${ }^{34}$.

The Hymn to Zeus is assumed to be the earliest of the $\operatorname{six}^{25}$ despite disagreement as to the year of its composition, which is variously dated between 286 and 270 B.C. The majority of scholars, however, favour a date 26 before 280 B.C. It is important to stress that Callimachus here is holding the Cretans alone $e^{27}$ guilty of the blasphemy of the grave. Since the hemistich is traditionally attributed to Epimenides one may wonder whether the celebrated Cretan seer, purifier and poet did rebuke his fellow-countrymen on account of their pretended Zeus' grave and accordingly branded them as liars, unwittingly involving himself too in this logical vicious circle $^{28}$. If this is the case -on condition that this hemistich is a genuine passage from a poem by Epimenides $^{29}$ — our written evidence for the existence of Zeus' grave must be antedated by two or three centuries, i.e. to around $600 \mathrm{~B}, \mathrm{C}$.

Epimenides' abuse of the Cretans is later quoted as a complete

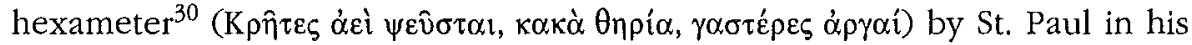
Epistle $A d$ Titum $(\varangle 12)$ with no explanation of the circumstance affecting the

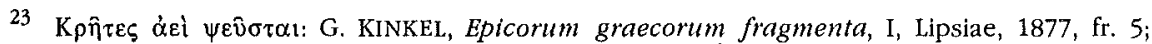
W. DIELS - H. KRANZ, Die Fragmente der Vorsokratiker; I, 1951 ${ }^{6}$, p. 31-32..

24 CALLIM., Hymn, 1, 4-7.

25 Cf. W. CHRIST - W. SCHMID, Geschicbte der griecb. Literatur, I, München, 1920, p. 135 ("gedichtet 283-280 B.C.").

26 See WINIARCZYK, op. cit. (n. 16), 2, n. 2.

27 This fact is unduly slighted by most scholars taking Callimachus' passage as a "reaction against Euhemerus and his philosophy": G.R. MACLENNAN, Callimacbus, Hymn to Zeus, Roma, 1977, p. 38; yet, see U. vON WILAMOWITZ, Euripides Hippolytos, Berlin 1891, p. 224, n. 1.

28 G.L. HUXLEY, Greek Epic Poetry, London, 1969, p. 81-82; but see M.C. LECLERC, Épiménide sans paradoxe, in Kernos, 5 (1992), p. 225-226.

29 The extant fragments presumably originate from later writers: H. DIELS, VS II, $1912^{2}$, p. 188 ; cf. SCHMID - STÄHLIN, Gescblcbte der griech. Literatur, I, 1, München, 1974 [1929], p. 305, etc.; Lobon of Argos (3rd cent. B.C.) -from whom Diogenes Laertius derives his material about Epimenides' works (I, 34, 111-112) - is deemed a deliberate forger.

30 An echo of the Hesiodic verse Theogony, 26. 
adverse criticism of "the Cretans' own prophet". Christian commentators, however, readily connected the verse with Zeus' tomb, at the same time charging Callimachus with misappropriating Epimenides' own testimony ${ }^{31}$.

In 1912 J.R. Harris ${ }^{32}$ attempted to reconstruct four verses supposedly belonging to a poem by Epimenides On Minos and Rhadamantbys, in which Zeus' son Minos was presented as eulogizing his divine father against the impious Cretan claim of the tomb. Harris' unconvincing attempt was founded upon an artificial compilation of phrases from the commentary on Acts 17, 28 by the Nestorian Bishop Isho'dad de Merv (c. 850 A.D.) - who in turn drew from Theodorus Bishop of Mopsuestia (c. 350-403 A.D.) - and extracts from Callimachus, Aratus and Cleanthes. What can be safely admitted is that, while the famous utterance assigned to Epimenides may be authentic ${ }^{33}$, its relation to the tomb motif remains unproved ${ }^{34}$. Callimachus' offensive against the rumoured Zeus' grave was again manifested in the 202, 15-16 fragment

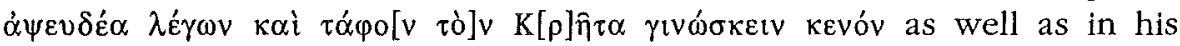
derogatory allusion to Euhemerus ${ }^{35}$.

Before we attempt a brief survey of the lasting effects which lines 8-9 of the Hymn to Zeus exercised on opposing social groups, it is worth commenting on a text which probably takes us back at least a century earlier and may shed some light on the question of Zeus' grave and the negative approach to it.

In the extant Certamen Homeri et Hesiod $3^{6}$ by an anonymous compiler of the Antonine period ${ }^{37}$ Hesiod tries to confound his rival rhapsode by putting forward the riddle: "Muse tell me about those events which neither have happened before nor shall ever betide now or in the future". Homer, however, wittily retorts: "Never will the steeds with galloping hoof-beats crash their chariots with each other round Zeus' tomb, as they eagerly compete for victory $^{\prime 38}$. In other words, the immortality of the supreme god entails both the unreality of the tomb tale ${ }^{39}$ and the impossibility of any funeral games being

31 Cf. EPIPHANIUS (bishop of Constanteia = Salamis of Cyprus, 367-403 A.D.), Panarion adversus baeres., 1, 3, $42(=P G, 41,793)$; HIERON., Comm. in Epist. ad Tit. VII, 606: dicitur iste verstculus in Epimen. Cret. poetae Oraculis reperirt; I, 166: cuius beroict bemistichium postea Callimacbus usurpavit.

32 Expositor, 1912, p. 348-353; cf. P. CHRISTOU, 'O 'A

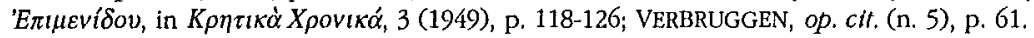

33 Cf. WEST, Hesiod Theogony, op. cit. (n. 6), p. 162.

34 Cf. U. VON WILAMOWITZ, Hellenistische Dichtung, II, Berlin, 1924, p. 3: "Am hübschesten wäre es, wenn Epimenides selbst von dem Grabe geredet hätte, aber das ist unerweislich".

35 R. PFEIFFER, Callimachus, I, Iambi, fr. 191, 9-11; [PLUT.], Mor., 880e.

36 U. VON WILAMOWITZ, Vitae Homeri et Hesiodi, Bonn, 1916 (Kleine Texte, 137), p. 34-45; T.W. ALLEN, Homerl opera V, Oxonii, 1952 (OCT), p. 226-238.

37 "Not long after Hadrian's death": M.L. WEST, The Contest of Homer and Hesiod, in CQ, 17 (1967), p. 433.

38 WILAMOWITZ, Certamen, op. clt. (n. 36), p. 37, 30-31 (= ALLEN, 100-101).

39 Exactly as in CALlimaCHus' Hymn to Zeus, 4-7. 
held round it. It is generally agreed ${ }^{40}$ that large parts of the Certamen narrative are taken over by the 2nd cent. A.D. compiler from the miscellaneous Mouseion of the sophist Alkidamas of Elaia in the Aeolis, a slightly older antagonist of Isocrates. His Mouseion was apparently published at the beginning of the 4 th cent. B.C., perhaps even earlier ${ }^{41}$. The theory (by Bergk, Allen a.o $)^{42}$ that the original source of Alkidamas - who depicted Homer as the first great exponent of extemporaneous speech- was the 7 th cent. cyclic poet Lesches, may be dismissed; yet Alkidamas retold the old popular story of the "contest", and the riddles, including the above cited, allegedly answered by "Homer", are thought to be "traditional" 43 . If so, one can plausibly speculate whether the same cause (as in Callimachus) of widespread rumours of Zeus' grave motivated Alkidamas too or his authority to relegate the story to the realm of unreality ${ }^{44}$. At any rate, Callimachus figures at the head of a long tradition of writers who use his verses either positively -i.e. subscribing to the rebuttal of the Cretan claim- or negatively, i.e. taking them as evidence for the existence of Zeus' real grave in Crete. Adherents to the former attitude are of course the conscious or feigned supporters of the religious establishment, one of whom, the poet Gaetulicus of the Flavian period, closely follows

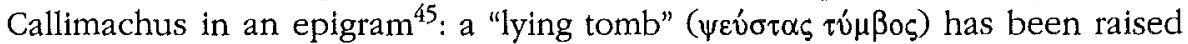
to cover the Cydonian Astydamas though the man was actually drowned while rounding Cape Malea. No wonder! Since "Cretans are liars and even Zeus has a tomb there" 46 .

More persistent is the treatment of Callimachus' passage by the Christian apologists of the early Church, who choose rather to ignore the Alexandrian poet's denial of the tomb: Tatian (c. 120-173 A.D) in his virulent polemic against the Hellenistic learning (Прòs "E $\lambda \lambda \eta \eta \alpha \varsigma \$ 27$ ) which is dated c. 155-165 A.D., returns to the pagans the imputation of atheism by reminding them of the grave of Olympian Zeus "even if one may accuse the Cretans of being liars"

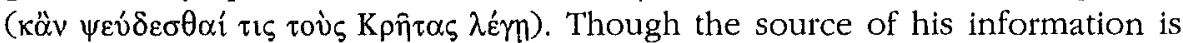

40 Cf. Fr. BLASs, Die attiscbe Beredsamkeit, II, Leipzig, 1892², p. 349-350; M.J. MILNE, A Study in Alcidamas and bis Relation to Contemporary Sopbistic [Dissert.], Pensylvania, 1929, passim; WEST, art. cit. (n. 37), p. 433-450.

41 Cf. MILNE, op. cit. (n, 40), p. 64: "perhaps before Aristophanes' Frogs and almost certainly before the completion of Thucydides' History".

42 More recently adopted by HUXLEY, op. clt. (n. 28), p. 160.

43 WEST, art. cit. (n. 37), p. 438-441; cf. R. PFEIFFER, History of Classical Scbolarship, Oxford, 1968 , p. 50.

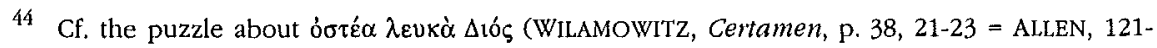
123).

45 Antbol. Palat., VII, 275. According to PAGE, Further Greek Eptgrams, Cambridge, 1981, p. 41, his dates are "within the first half of the 1st cent. A.D. or even earlier".

46 Gaetulicus of course imitates earlier models in sepulcral epigrams, that speak of cenotaphs as "lying tombs", cf. CAllimachus (Antbol. Palat., VII, 271), LEONIDAS OF TARENTUM (VII, 273), HONESTUS OF BYZANTIUM (VII, 274). 
not specified, it is obvious that Tatian draws ${ }^{47}$ - directly or indirectly- from Callimachus with the latter's retrospection to Epimenides' saying. A few years after Tatian ${ }^{48}$ the "Athenian Philosopher and Christian" Athenagoras is more explicit: in his Plea for Christians -addressed to the co-emperors Marcus Aurelius and Commodus between 176 and 178 A.D.- he quotes the verses 8-9 and blames the Alexandrian poet for contradicting himself: for whereas he admits Zeus' birth in Arcadia he denies his burial place in Crete. But "the uncreated God is alone eternal". The same verses (8-9) of Callimachus' Hymn are quoted also by Clement of Alexandria (c. 150-c, 215 A.D.) in his Exbortation to the Greeks": "Leda is dead; the swan is dead; the eagle is dead. Search for your Zeus. Search thoroughly not heaven but the earth. The people of Crete $\mathrm{e}^{50}$, where he is buried, will tell you; Callimachus in his hymns: $\kappa \alpha i$ $\gamma \grave{\alpha} \rho$

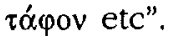

Probably a few years before Clement and using rhetorical questions and answers, yet without verbatim quoting or naming Callimachus, Theophilus of Antioch (bishop 170-180 A.D.) had stressed the mortality of Zeus by reference

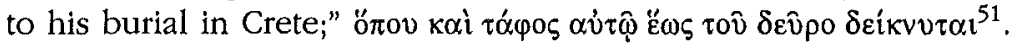

In the year 178 A.D. Lucian's friend and Platonic philosopher Celsus published the first serious criticism of Christianity under the heading The True Discourse ('A $\lambda \eta \theta \dot{\eta} \varsigma$ $\Lambda$ ó ${ }_{0 \varsigma}$ ). About 70 years later ${ }^{52}$ Origen (c. 184-c. 254) refutes Celsus' censure that although the Christians sneer at the pagans for

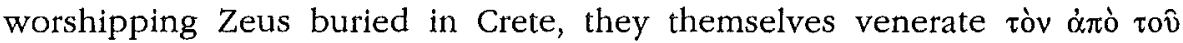
$\tau \alpha \dot{\alpha} \varphi v^{53}$. Callimachus is again summoned from the opposite camp to verify Origen's thesis with the same couplet (v. 8-9); nevetheless, the Alexandrian poet is blamed by Origen for ignoring that Zeus' birth in Arcadia is correlative to his death ${ }^{54}$.

III. A second line of thought in the tomb tradition stems from the Sacred Record ('I $\varepsilon \rho \dot{\alpha}$ 'Av $\alpha \gamma \rho \alpha \varphi$ ), the notorious fiction circulated in Alexandria by

47 Tatian "in early life was trained in the learning of the Greeks and gained great distinction": EUSEB., Eccles. Hist., 4, 16, 7.

48 See W.R. SCHOEDEL, Atbenagoras, Legatio and De Resurrectione, Oxford, 1972, p. XI.

49 Protrept., 2, 37, 4.

50 The passage is curiously mistranslated by G.W. BUTTERWORTH in the Loeb edition (Clement of Alexandria, The Exhortation to the Greeks, 1982 [1919], p. 78) as "Callimachus the Cretan (1), in whose land he (i.e. Zeus) lies".

51 Ad Autol, 2, 3; cf. 1, 10. G. BARDY (Théopbile d'Antiocbe, Trots livres à Autolycus, Paris, 1948 [Sources cbrétiennes, 20], p. 78) contends that the apologist "ne sait pas en réalité si, de son temps,

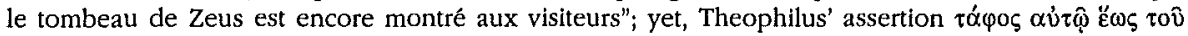
$\delta \varepsilon \hat{p} \delta_{0} \delta \varepsilon \kappa v v \tau \alpha \imath$ points in the contrary direction.

52 ORIGEN, Contra Celsum (written probably in 248 A.D.).

53 Ibid., 3, 43.

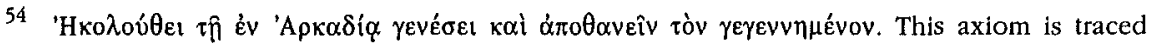
back to the Epicureans, the consolatory literature and sepulcral epigrams. 
Euhemerus (flor. 300 B.C.) of Messene - the Peloponnesian or the Sicilian town - who professed to have undertaken distant journeys in the service of King Cassander (317-298 B.C.). Euhemerus' not very original ${ }^{55}$ theory - embedded into a geographical-political framework - on the origins of the gods as deified former kings attracted Callimachus' scorn: he is depicted as "the babbling old man who has concocted the Panchaian Zan and scrawls blasphemous books ${ }^{56 "}$.

That both writers chanced to head the long succession of testimonia on Zeus' grave does not necessarily carry the conclusion that "cette croyance est restée limitée à un petit groupe d'évhémèristes" nor that "n'était certainement pas la conception généralement répandue parmi les Crétois"57.

The chronological order of events should rather be reversed to agree with Edwin Rohde's ${ }^{58}$ old observation that Euhemerus "die Sage, als zu seinem kläglichen Mythen-pragmatismus scheinbar trefflich passend, hervorgezogen und in die Literatur eingeführt habe" 59 . For, indeed, several points in Euhemerus' narrative suggest his indebtedness to Cretan religious folklore, e.g. the alleged presence of Cretan immigrants in the society of Panchaia; the privileged position of the Panchaian priests claiming a Cretan ancestry, since they were brought to the island by Zeus from Crete in the course of his earthly reign ${ }^{60}$; the use of Cretan words etc. Though not isolated in an age of bizarre travel stories and a rationalistic approach to mythology, Euhemerus' book had far-reaching consequences. Whether or not generated by tendencies in the Ptolemaic court ${ }^{61}$, it certainly encouraged the rise of ruler-cults among the successors and Epigonoi of Alexander by providing them with supposedly historical precedents ${ }^{62}$. On the other hand, as a document of humanistic godlessness it became the target of polemics from philosophic schools and followers of the official religion but also an invaluable weapon in the hands of Jews and Christian apologists. In the Greek speaking East Euhemerus' pronouncements are taken seriously by Polybius and fully adopted by Diodorus; but Eratosthenes, Apollodorus, Strabo and Plutarch dismiss them as spurious.

55 P. DECHARME, La critique des traditions religteuses chez les Grecs, Paris, 1904, p. 372-374;

P. WENDLAND, Die Hellenistiscb-Römiscbe Kultur, Tübingen, 1912, p. 120.

56 See supra, n. 35.

57 VERBRUGGEN, op.cit. (n. 5), p. 68.

58 Op. cit. (n. 14).

59 Cf. S. SPYRIDAKIS, Zeus is dead. Eubemerus and Crete, in CJ, 63 (1968), p. 340; J. FERGUSON, Utoplas of the Classical World, London, 1975, p. 104.

60 DIOD. SIC., 5, 45, 3-5; 5, 46, 3.

61 Cf. J. HANI, La religion égyptienne dans la pensée de Plutarque, Paris, 1976, p. 137.

62 M. BROZEK, in Meander, 25 (1970), p. 249-261, 299; cf. M. GRANT, From Alexander to Cleopatra, London, 1982, p. 256; S. BLUNDEL, The Origins of Civilization in Greek and Roman Thought, London-Sydney, 1986, p. 171. 
In the latin West, however, the authority of the poet Quintus Ennius (239169 B.C.), who published (between 201 and 181 B.C.) an adaptation of either the entire 'I $\varepsilon \rho \dot{\alpha}$ 'A $\alpha \alpha \gamma \rho \alpha \varphi$ ' or a part of it, probably in prose, under the heading of Sacra Historia - or Sacra Scriptio or Eubemerus- secured a far greater following despite occasional reaction. Thus, in Cicero's De natura deorum ${ }^{63}$ the academic C. Aurelius, after attacking Epicurus, Protagoras and Prodicus on account of their rationalizing of divinities, aims his arrows at Euhemerus by whom mortes et sepulturae demonstrantur deorum. As a result Euhemerus videtur religionem totam sustulisse ${ }^{64}$. Again in Bk III 53 the attack is resumed against those qui bos deos ex bominum genere in caelum translatos non re sed opinione esse dicunt. In the course of the dialogue homonumous deities are differentiated and of the three "Joves" the third is styled "Cretan, son of Cronus, whose grave is demonstrated in that island" (cuius in illa insula sepulcrum ostenditur). Also Cicero's biographer, the platonizing ${ }^{65}$ Plutarch inveighs Euhemerus' stories as "quackeries" ( $\left.\varphi \varepsilon v \alpha \kappa i \sigma \mu 0^{\prime 66}\right)$. Their author "after drawing up copies of an incredible and non-existent mythology, spreads all manner of atheism over the entire inhabited world; indeed he obliterates all our accepted gods by uniformly reducing them to names of generals, admirals and kings, who allegedly lived long ago and are recorded in golden letters at Panchon; yet neither a foreigner nor any Greek has come across them except Euhemerus himself, who, it seems, alone sailed to the Panchoans and Triphyllians who never existed nor do they live today anywhere on earth ${ }^{67 " \text {. }}$ Euhemerus' doctrine, however, was made popular following Diodorus Siculus' publication of the Bibliotheca, in which excerpts and epitomes of the "Sacred Record" were intertwined with pertinent sources and the historian's own points of view ${ }^{68}$. Jews and Christians alike take advantage of Diodorus' testimony to fight pagan polytheism. Of the miscellaneous collection of oracles known as Oracula Sibyllina the first section (hexameters 1-216) of the 8th book (admittedly dated before Marcus Aurelius' death ${ }^{69}-180$ A.D. or, more

63 Written c. 45 B.C. with a dramatic time set between 77 B.C. and 76 B.C.: M. BRUWAENE, Cicéron, De natura deorum, I, Bruxelles, 1970, p. 6. Cicero used Ennius' version rather than the original Greek text.

64 CIC., De nat. deor., 1, 119; on Cicero's sources see WINIARCZYK's edition of Euhemerus (10 T 14).

65 K. ZIEGLER, Plutarcbos von Chaironeta, Stuttgart, 1949, p. 302.

66 PLUT., On Isis and Osiris, $23(=$ Mor, 360a-b).

67 The faulty names of the island and of its inhabitants, plus the listing of generals and admirals as allegedly awarded divinity status, imply Plutarch's use of an indirect source rather than Euhemerus' text: G. NÉMETHY, Eubemert reliquiae, Budapest, 1889, p. 12; G. VALLAURI, Evemero di Messene, Torino, 1956, p. 48; J.G, GRIFFITHS, Plutarch, De Iside et Osiride, Cambridge, 1970, p. 380, etc.

68 K. THRAEDE, Eubemertsmus, in RAC, VI (1966), p. 878.

69 J. GEFFCKEN, Komposition und Entstebungszeit der Oracula Sibyllina, Leipzig, 1902, p. 38; cf. D.S. POTTER, Prophecy and History in the Crists of the Roman Empire, Oxford, 1990, p. 99. 
precisely, c. 175 A.D. ${ }^{70}$ - and whose authorship is Jewish ${ }^{71}$ rather than Christian $^{72}$ ) predicts the end of the world and the collapse of Rome which is accused of injustice and idolatry $(45-49)^{73}$ :

$\pi 0 \hat{v}$ 'Peíns jù Kpóvoto

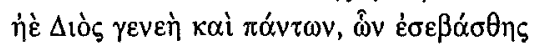

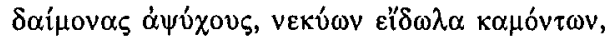

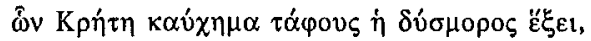

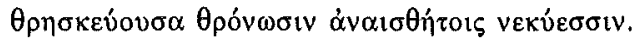

Significantly, Crete is portrayed here as boasting about the graves of bygone rulers, this detail no doubt reflecting the prevailing opinion of the outside world ${ }^{74}$.

The Verses 47-48 will soon be declared by Lactantius (Div. inst. I, 11, 47) as a confirmation of the preceding lines of Ennius' on Zeus' administrative arrangements, his death in Crete and the burial rites performed by his sons Curetes: aetate pessum acta in Creta vitam commutavit et ad deos abiit eumque Curetes filii sui curaverunt decoraveruntque eum; et sepulcrum est in Cret $a^{75}$... Lactantius' wrong belief in the remote antiquity of all the "Sibylline oracles" is unanimously shared by Church fathers ${ }^{76}$ against outspoken charges by pagan intellectuals -e.g. Celsus ${ }^{77}-$ to the effect that numerous interpolations into the old stock were intentionally devised by the Christians in order to buttress their own faith. In particular, the argument about Zeus' tomb was recalled during their hearings before Roman proconsuls or the Senate by the early martyrs Ignatius ${ }^{78}$ (d. 108 A.D.) and Apollo(niu)s - "also called Sakkeas"- executed under Commodus (c. 183-185 A.D.) according to the extant Acta $^{79}$ which in fact subsequently suffered apologetic alterations. Nevertheless, since Apollonius, in the words of Eusebius ${ }^{80}$, "was famous among the Christians for his education and philosophy" and his apology to the Roman

\footnotetext{
70 J. COLLINS, The Development of the Sibylline Tradition, in ANRW, II, 20.1 (1987), p. 447.

71 A. RZACH, Sibyllinische Orakel, in RE, II A 2 (1923), col. 2144; cf. COLLINS, art. cit. (n. 70).

72 As maintained by GEFFCKEN, op. cit. (n. 69), p. 44.

73 J. GEFFCKEN, Die Oracula Sibyllina, Leipzig, 1902.

74 Cf. Hieron., In epist. Pauli ad Titum, 26, 573 Migne: Cretenses qui sepulcrum elus ostendere gloriantur.

75 See supra, n. 16.

76 E.g. HERMAS, Shepherd, 2, 4; [Justin], Cobort. ad gent., 38; THEOPHILUS, Ad Autol, 2, 31; A'thenagoras, Legatto, 30, 1; Clem. AleX., Cob. ad Graecos, 2, 4, 6, 7, 8, 10; ID., Paed., 3, 3; Strom., 1,$15 ; 21$, etc.

77 ORIGEN, Contra Celsum, 7, 53; cf. LACT., Divin. Inst., 4, 15, 26.

78 A. DRESSEL, Patrum apostolicorum opera, Lipsiae, 1857 (Martyr, 7), p. 354.

79 H. MUSURILLO, The Acts of the Christian Martyrs, Oxford, 1979 [1972], n 7, 22, p. 96.

80 Eccles. Hist., 5, 21
} 
senate proved "a most learned one", he naturally invoked such salient features of heathenism as Dionysus torn to pieces, Heracles brought to the flames alive and Zeus' interment in Crete.

During the same period bishop Theophilus of Antiocheia (169-c. 180 A.D.) -apparently trusting compendia with lists of atheists- brands Euhemerus as "the most atheistic philosopher" ${ }^{11}$ though elsewhere (Ad Autol. 1, 10; 2, 3) he twice cites the Euhemeristic stock argument of Zeus' grave. In contrast to Theophilus and other Greek apologists, Clement of Alexandria (died before 215 A.D.) exonerates Euhemerus ("of Acragas"!) and a good many others from the stigma of godlessness on the grounds that these thinkers "discerned more acutely the error connected with the alleged gods even if they did not perceive the truth itself" 82 .

In direct line with Justin Martyr, Clement of Alexandria and Origen, bishop Eusebius of Caesarea (c. 260-340 A.D.) - " in some ways the last and greatest of the Apologists"83 — uses Euhemerus' doctrine at second hand, through the medium of Diodorus ${ }^{84}$, whom he praises as "most notable amongst the Greek erudite intellectuals". In his Praeparatio Evangelica Eusebius quotes extensively from Diodorus' 3rd book, including his reference to Zeus' grave, with slight verbal changes ${ }^{85}$. A valuable fragment from Diodorus' lost 6 th book ${ }^{86}$ is also found in Eusebius. The accumulation of lengthy extracts on religion from Diodorus and other ancient writers purports to convince the intellectual elite of the opposite camp about the absurdities of their divinities. Thus Eusebius gratefully endorses Clement's refutation of the traditional cults ${ }^{87}$ as expounded in the Cobortatio ad Graecos more than a century earlier.

The apologists of the western provinces of the Roman empire naturally drew on Ennius' version of Euhemerus' book though few of them acknowledge their indebtedness as well to Greek apologetic tracts or Diodorus' text. Around 197 A.D. Tertullian ${ }^{88}$ (c. $160-230$ A.D.) who was born in Carthage, addressing his Apologeticum to the Roman provincial administrator, calls upon Diodorus' statement on Saturnus' human nature (Apolog. 10, 7: Saturnum ... neque aliud quam bominem) while elsewhere (Ibid. 25,7$)$ he sarcastically taunts with the worship of Zeus, "who would not allow his Crete to be subdued by Romans" (Cretam suam Romanis fascibus) and omni Capitolio tumulum illum suum

\footnotetext{
81 Ad Autol., 3, 7.

82 ClEM. AlEX., Coh. ad Graecos, 2, 24, 2. Clement does not have a first hand acquaintance with Euhemerus' text: NÉMETHY, op. cit. (n. 67), p. 18; ZUCKER, in Pbilologus, 64 (1905), p. 468.

83 K. LAKE, Eusebius, The Eccles. History, I, Cambridge Mass., 1980 [1926] (Loeb), p. XVI.

84 Cf. Praep, evang., 2, 3, 52; 3, 54; 3, 55; 3, 62.

85 Cf. DIOD. SIC., 3, 61, 2 = EUSEB,, Praep. evang, 2, 3, 48 and 3, 10, 21 .

86 DIOD. SIC., 6, 1 = EUSEB., Praep. evang, 2, 3, 57.

87 EUSEB., Praep. evang., 2, 3, 64.

88 The first writer to initiate theological terminology into Latin.
} 
praeposuisset, ut ea potius orbi terra praecelleret quae cineres Jovis texit. Perhaps a few years later Minucius Felix, a Roman lawyer and probably Tertullian's fellow-citizen, wrote the dialogue Octavius in which his lifelong Christian friend Octavius Januarius urges the skeptic pagan Caecilius Natalis to consult the writings of wise men and historiographers, who equate the false gods with mortals. Euhemerus in particular describes their eventual deifications ob merita virtutis aut muneris (Octav. 21, 1) and enumerates their mothercountries and graves (eorum natales patrias sepulcra dinumerat). Then the historians are referred to (Nepos, Cassius, Thallus and Diodorus) who bear witness to the same facts, namely "that Cronus' son expelled his father and ruled over Crete, where he died; Zeus' cave is still being visited and his tomb shown off; even the rites performed there prove his human nature" 89 .

Another rhetorician of some note in the African province who turned Christian, Arnobius - from Sicca Veneria of Numidia yet probably of Greek extraction ${ }^{90}-$ in his hastily composed Adversus nationes (dated between 297 and 311 A.D.) adopts the habitual arguments of the earlier apologists -above all of Clement of Alexandria, whose error regarding Euhemerus' birthplace ${ }^{91}$ he inadvertently repeats. Arnobius extolls Euhemerus and the other "atheists", who scrupulosae diligentiae cura brought to light res abditas ${ }^{92}$ of the heathen gods, e.g. of Zeus, who tertius vero Saturno (i.e. patre progenitus) apud insulam Cretam et sepulturae traditus et procreatus ${ }^{93}$. Arnobius' inference is of course the typical one: possumus quidem ... omnis istos, nobis quos inducitis atque appellatis deos, bomines fuisse monstrare ${ }^{24}$.

To Arnobius' celebrated pupil Lactantius -born in Africa before 250 A.D. ${ }^{95}$ - we owe the survival of a large number of verbal quotations or paraphrases from Ennius' Sacra Historia in his major work Divinae Institutiones (= Divine Precepts) and their Epitome written afterwards on someone's request. The first ${ }^{96}$ of the seven books of Div. Inst. comprises Euhemerus' information on pagan gods, mainly of Zeus' worldly career until his

89 MIN. FELIX, Octav., 21, 8: eius flitus Jupptter Cretae excluso parente regnavit, illic oblit, illic filios babuit; adbuc antrum Jovis visitur et sepulcrum elus ostenditur, et ipsis sacris suls bumanitatis arguitur, cf. bishop CYPRIANUS (d. 258 A.D.), De idol. van., 2.

90 H. LE BONNIEC, Amobe, Contre les Gentlls, I, Paris, 1982 (C.U.F.), p. 7, n. 3.

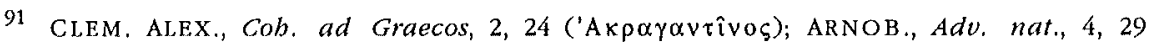
(Agragantimus).

92 ARNOB., ibid.; cf. R. HIRZEL, Die Homonymie der griech. Götter nach der Lebre antiker Theologen, in Berichte u. Verh. d. Königl. Säcbs. Gesellsch. zu Letpzig, Pbll.-Hist. Cl., 48 (1896), p. 281 .

93 ARNOB., Adv. nat., 4, 14; cf. 4, 25: apud insulam Cretam sepulturae esse mandatum Iovem nobis editum traditur.

94 Ibid., 4, 29.

95 J.L. CREED, Lactantius, De mombus persecutomu, Oxford, 1984, p. XXV.

96 Entitled De falsa religione: S. BRANDT, L. Caell Firmiani Lanctanti, Opera omnia, I: Divinae institutiones et Eptome Div. inst., Pragae-Vindobonae-Lipsiae, 1890. 
death and burial in Crete ${ }^{97}$. The evidence from Euhemerus -whom Lactantius holds to be a trustworthy historian ${ }^{98}$ - is supplemented with verses from the forged "Sibylline Oracles", which — as noted above- Lactantius accepts without any hesitations as authentic ancient documents. Accordingly, he arrives at the same conclusion as his forerunners (Epitome Div. Inst. 13): Constat ergo ex is quae rettuli, bominem fuisse (i.e. Jovem) in terramque regnasse.

About a century later Aurelius Augustinus (St. Augustine) bishop of Hippo (354-430 A.D.) - presumably depending on Cicero's De natura deorum, Lactantius or other unidentifiable sources- refers vaguely to Euhemerus' stories and Ennius' Latin translation ${ }^{99}$ concerning Zeus' earthly life and mortality but "eschews dwelling on this topic since a great deal has been set down thereon by those who have written before us either in Greek or Latin against such errors" 100 .

IV. What has been discussed so far can be summed up as follows: a) a distinctive feature of a persisting worship of a vegetation divinity, that dies and is reborn annualy, is the acceptance of Zeus' grave in Crete; b) as this Cretan peculiarity progressively gains wider notoriety through literature and hearsay it draws forth a hostile response - as a fraudulent artifice- from supporters of the religious establishment whereas it is variously utilized by the monotheistic creeds of Judaism and the Church. Perhaps within this context of ideological controversy, which is clearly reflected in the increasing numbers of apologetic tracts during the 2nd and 3rd centuries A.D., we have to register Antiochus' "Apology" in defence of the Cretans with which this paper is introduced. Yet this context has not helped to clarify the nature or the arguments used by the sophist in his declamation. On the other hand it is hazardous to seek any relevance of the biographical data to the question in hand; according to Philostratus (Vit. Soph. 568) Antiochus used to spend many nights in the temple of Asclepius at Aegae ${ }^{101}$ on account of the dreams he had there and his personal contact with the healing god - but this can only point to the sophist's excessive pietism. Moreover, his "perfect" erudition in matters of history and mythology is extolled by the decree in his honour from the Peloponnesian Argos, which he allegedly discovered to be the metropolis of his own birth town Aegae, since the latter was colonized by Perseus during his expedition

97 Cf. supra, n. 16 and 75.

98 Div. Inst., 1, 11, 33: antiquus auctor... res gestas Iovis et ceterorum qui dil putantur collegit; Epitome, 1, 1, 47: Hoc... tradunt antiquarum rerum scriptores.

99 AUGUST, De civ. Dei, 6, 7; 7, 27; De cons, evang., 1, 23, 32; Epist., 17, 3.

100 De civ. Det, 7, 27: quia plurima posuerunt, qui contra buius modi errores ante nos vel Graeco sermone vel Latino scripserunt, non in eo mibi placuit immorart.

101 The same sanctuary was used for residence by Apollonius of Tyana: PHILOSTR, Vita Apoll., 1,8 . 
against the Gorgons ${ }^{102}$. More positive clues should rather be sought in dominant interpretive trends at the time.

In his True Discourse against the new Creed -as it is excerpted by Origen-Celsus censures the Christians for jeering at the pagans for worshipping Zeus, whose grave is shown in Crete, though themselves adore as

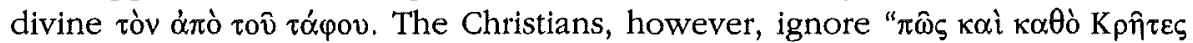

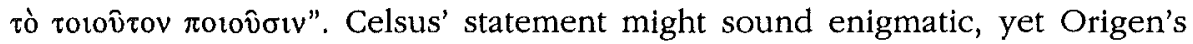

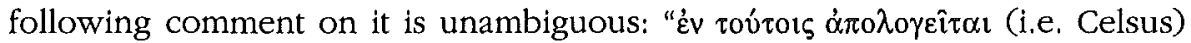

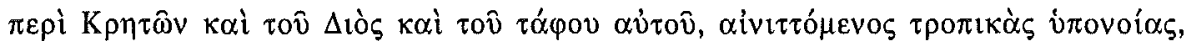

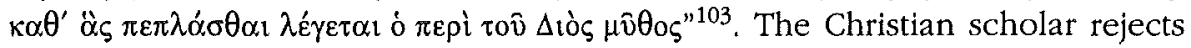
such methods of overcoming the oxymoron i.e. by reading hidden or symbolic meanings into the Cretan religious practice; he in his turn summons Callimachus again from the heathen camp to bear witness to the historical fact: "Indeed, the Cyrenian poet who read through the greatest number of poems and practically the entire Greek history does not know of any allegorical sense in connexion with Zeus and his grave ${ }^{104}$. Accordingly, the poet accuses the Cretans in his hymn to Zeus" - then is cited the notorious couplet hypothetically derived from Epimenides ${ }^{105}$. Celsus ("the enlightened advocate of the reformed paganism") elsewhere ${ }^{106}$ appears to defend the Egyptian cult images of animals - derided as well by the Christians - as instead intimating "eternal ideas". The vindication of traditional beliefs and cults through allegorical interpretations is not peculiar to Celsus; it has been widely practised ever since it was initiated in the sixth cent. B.C. by the rhapsode Theagenes of Rhegium $^{107}$ (fl. 525 B.C.) or perhaps by his predecessor Pherecydes ${ }^{108}$ of Syros in reply to the strictures from Pythagoras' or Xenophanes' schools against the blasphemous representation of gods in Homer and Hesiod. The term used in the classical period to indicate a deeper sense supposedly underlying the literal

102 W. VOLLGRAFF, in $B C H, 28$ (1904), p. 421-424; A. WILHELM, in BCH, 29 (1905), p. 576; H.J. POLLACK, in Mnemosyne (1906), p. 335-338; L. \& J. ROBERT, op. cit. (n. 1), p. 318; L. ROBERT, in $B C H$, 101 (1977), p. 126; cf. SPAWFORTH-WALKER, in $J R S, 126$ (1986), p. 103 sq. and -more recentlyA. CHANIOTIS, Historie und Historiker in den grlechischen Inschriften, Stuttgart, 1988, p. 85 (T 20), $116,322-324$ (E 28).

103 ORIGEN, Contra Celsum, 3, 43. Nevertheless, Celsus censures the Christians for resorting to the expediency of allegorism. This situation of blatant inconsistency and reciprocal strictures is fittingly described by J. GEFFCKEN (Zwet griecbiscbe Apologeten, Leipzig-Berlin, 1907, p. 82) as "ein wahres Chaos inkonsequenter Polemik".

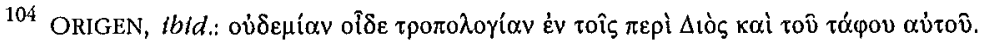

105 See supra, n. 31, 32.

106 ORIGEN, ibid., 3, 19.

107 CF, SCHMID-STÄHLIN, op. cit. (n. 29), p. 130, 745; J.E. SANDYS, A History of Classical Scbolarship, I, Cambridge, 1958, p. 29 sq.; R. PFEIFFER, op. cit. (n. 43), p. 9-10.

108 J. TATE, The Beginnings of Greek Allegory, in $C R, 41$ (1927), p. 214-215. 
or superficial one was $\dot{i} \pi$ óvol $\alpha^{109}$ which was later replaced by $\dot{\alpha} \lambda \lambda \eta \gamma$ opí $\alpha^{110}$. Theagenes was credited with distinguishing two forms of allegory (physical or moral) and with regarding the divine names as suggestive of mental faculties (Athena $\sim$ Ares; Hermes $\sim$ Leto) or natural forces (Apollo $\sim$ Poseidon; Hera $\sim$ Artemis). Pherecydes — according to Celsus ${ }^{111}$ — read a cosmological meaning into the abusive words of Zeus to Hera (Il, 15, $18 \mathrm{ff}$.) allegedly addressed by the god to matter, which was in a confused state. About the middle of the 5 th cent. B.C. Anaxagoras' pupil Metrodorus of Lampsacus "turned everything to allegory" - to quote Tatian's ${ }^{112}$ derogatory comment- maintaining that Hera, Athena and Zeus were elements of nature. He even extended his "physical" explanation to cover the heroes of the Trojan war as well.

In contrast to the sophists, Plato and Aristotle - who all rejected such aberrations - allegorism apparently influenced members of the Orphic sect in the 4th. cent. B.C. and found ardent supporters amongst leading Stoics, e.g. Zeno of Citium (364-263 B.C.), Cleanthes of Assos (331-232 B.C.) and above all Chrysippus of Soloi (c. 280-208 B.C.). Concerning the latter, Cicero ${ }^{113}$ humorously remarks that "Chrysippus wants to adjust the tales in Orpheus, Musaeus, Hesiod and Homer to what he has said himself about the immortal gods, so that even the most ancient poets seem to have been Stoics". In imperial times the popularity of allegorical treatment of the offensive epic passages and myths ${ }^{114}$ is evidenced by the circulation of books such as $\mathrm{L}$. Annaeus Cornutus' Theologiae Graecae Compendium, Heraclitus' Quaestiones Homericae, Porphyry's De antro Nympharum etc., the adoption of similar techniques in the exposition of perplexing biblical texts by Jewish scholars and Christian apologists and the revival of allegorism in an exaggerated form by the Neoplatonists.

The Christians in general condemned the recourse to ítóvot $\alpha$ in the explanation of the ancient myths by pagan philosophers and grammarians seeking to $\theta \varepsilon \rho \alpha \pi \varepsilon \hat{v} \sigma \alpha \imath$ tò $\pi \alpha \tau \rho \imath$ kò $\dot{\alpha} \mu \alpha \dot{\alpha} \rho \tau \eta \mu \alpha^{115}$. One of the earliest apologists Marcianus Aristides ("the philosopher from Athens") in his Apology-according to Eusebius ${ }^{116}$ addressed to Hadrian (117-138), yet more likely to Antoninus

\footnotetext{
109 XEN., Symp., 3, 6; PLATO, Rep., 378d.

${ }^{110}$ PLUT., De aud. poet., 4 (= Mor., 19e); yet $\alpha \lambda \lambda \eta \gamma$ opı $\hat{\omega} \varsigma \varsigma$ occurs already in Cleanthes (331-231 B.C.),

111 ORIGEN, Contra Celsum, 6, 42.

112 Adversus Graecos, 21.

113 De nat. deor, 1, 41.

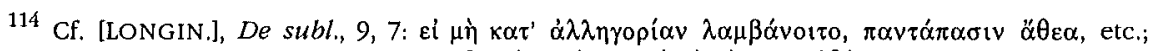

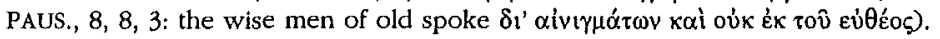

115 EUSEB., Praep. evang., 2, 6, 17.

116 ID., Eccles. Htst., 4, 3; cf. F. BÜCHSEL, Apologetlk, in RLAC, I (1950), p. 539-540.
} 
Pius (138-161) - concludes that if the stories about gods are mythical or "physically" allegorized, they are no more gods but myths and nothing else ${ }^{117}$.

Justin's pupil Tatian appeals to the heathen 118 "not to allegorize either their myths or their gods"; otherwise their conception of divinity is ruined not only by the Christians but by themselves. Tatian also disparages Metrodorus' arguments about gods as totally absurd since they represent the deities as natural substances.

On a similar pattern of argumentation, but with a substantially wider learning ${ }^{119}$ in the mythological and literary fields, Athenagoras rejects the

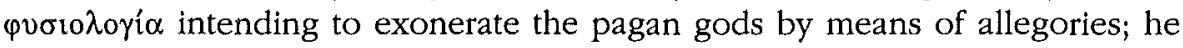
quotes Empedocles' "physical" equations (Zeus = Shining, fire; Hera = lifegiving, earth; Aidoneus $=$ air; Nestis $=$ water $^{120}$ ) and Stoic etymological speculations $^{121}$ without ignoring the current Euhemeristic tradition ${ }^{122}$.

From the preceding - by no means exhaustive - survey of texts written near the times when the sophist Antiochus was active (2nd and 3rd cent A.D.) it becomes fairly clear that metaphors and allegorical speculations ("physical", moral or etymological) are constantly resorted to when dealing with offensive myths and passages of the classical heritage. This technique of inovor $\alpha$ seems to appeal rather to enlightened and philosophical defenders of the accepted religion; at the same time it proves to be an admirable expedient in order to invalidate repeated attacks by atheists, skeptics, the Jews and the Christians. Perhaps we ought to reconstruct in this particular context the arguments contained in Antiochus' apology for the Cretans and understand accordingly

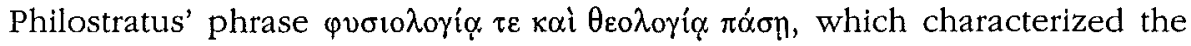
sophist's rhetorical arsenal used in the declamation.

25, Erechtheiou

Minos KOKOLAKIS

GR - 11742 ATHENS

117 ARISTIDES, Apol., 13, 7 .

118 Ad Graecos, 21, 6. He probably broke away from the Church in 172 A.D.: J. WHITTAKER, Tatian Oratio ad Graecos, Oxford, 1982, p. IX.

119 SCHOEDEL, op. cit. (n. 48), p. XIX-XX.

120 EMPEDOCLES, fr. 6 (= ATHENAG., Legat., 22, 1-2).

121 ATHENAG., Legat., 22, 4.

122 Cf. SCHOEDEL, op. cit. (n. 48), p. XXI. 